\title{
Tracing the tin-opacified yellow glazed ceramics in the western Islamic world: the findings at Madīnat al-Zahrā'
}

\author{
Elena Salinas ${ }^{1^{*}}$, Trinitat Pradell ${ }^{1 \dagger}$, Michael Tite ${ }^{2}$ \\ ${ }^{1}$ Physics Department and Barcelona Research Center in Multiscale Science and Engineering, \\ Universitat Politècnica de Catalunya, c/Esteve Terrades 8, 08860 Castelldefels, Barcelona, \\ Spain
}

${ }^{2}$ Research Laboratory for Archaeology and the History of Art, Dyson Perrins Building, South Parks Road, Oxford OX1 3QY, UK

\begin{abstract}
A small group of opaque yellow glazed sherds has recently been identified among the ceramics excavated at the Islamic city of Madīnat al-Zahrā' near Cordoba, in al-Andalus (southern Spain), which was founded in $936 \mathrm{AD}$ as the seat of the Umayyad Caliphate power. A small group of sherds from Madīnat al-Zahrā', which can be dated to about 960-980 AD, have been examined in polished section in a SEM with EDS attached. These analyses have established that the Madinnat al-Zahrā' sherds were opacified with lead stannate, and not lead antimonate, as was being used to opacify yellow glazed ceramics in Egypt and Tunisia in the $9^{\text {th }}$ and $10^{\text {th }}$ centuries AD. Islamic opaque yellow glazed ceramics, with lead stannate as the opacifier, were first produced (Watson 2014), in Egypt and Syria in $7^{\text {th }} / 8^{\text {th }}$ centuries $\mathrm{AD}$, and from there the technology spread eastwards into Iraq and Iran in $9^{\text {th }}$ century $\mathrm{AD}$, and continued in use in Iran and Central Asia into the $10^{\text {th }}$ century $\mathrm{AD}$ and beyond. However, the question of where these opaque yellow glazed ceramics were produced has not been fully resolved. Because such ceramics are extremely rare in al-Andalus, it seems most likely that they were either imported from Iran or Central Asia, or produced locally by potters arriving from these areas. The study adds one further, yet not fully understood chapter to the story of a persistent glaze technology which has been widely ignored.
\end{abstract}

Keywords: Opaque yellow glazes, Lead stannate, Lead Antimonate, Islamic, Umayyad Caliphate, Spain, Iran, Central Asia, Egypt, Tunisia, SEM-EDS, XRD

\footnotetext{
*Corresponding author. E-mail address: maria.elena.salinas@upc.edu. Telephone: +34 935521053. ORCID: 0000-0002-8306-3538

${ }^{+}$ORCID: 0000-0002-8720-5492
} 


\section{Introduction}

Madīnat al-Zahrā', "the Brilliant City", is an archaeological site located in the south of Spain (Figure 1A), which was founded by 'Abd al-Rahman al-Nasir, in $936 \mathrm{AD}$, after his selfproclamation as Caliph. 'Abd al-Rahman III was a descendant of the Umayyad dynasty in alAndalus, who decided to build a new city to compete with the large capital cities being constructed at that time by the Abbasids in Iraq and their enemies, the Fatimids in North Africa (Vallejo 2013).

Madīnat al-Zahrā' was built some seven kilometres west from Madīnat Qurtuba, the current city of Cordoba, that had, until then, been the capital of the Umayyad Emirate in al-Andalus from $8^{\text {th }}$ century AD onwards. The new capital was built on the edge of the mountain range, which allowed it to be organised in three large terraces (Figure 1B): the upper two being occupied by the Alcazar, with a dual function of containing the private residence of the Caliph, and the administrative offices required by the seat of the Umayyad Caliphate power; and the third terrace, the Medina, being occupied by the general population and servants. The city began to be settled around $940 \mathrm{AD}$, and continued in use until the sacking between 1009-1013 $\mathrm{AD}$ by the Berbers, the troops of Sulayman al-Mustain, as a consequence of the fitna or civil war (Vallejo 2013).

$<$ Figure $1>$

Among the ceramics excavated at Madīnat al-Zahrā' are a small group of opaque yellow glazed sherds, 177 on total. The majority (152) were found in the early $20^{\text {th }}$ century, and as a result, their exact location is not known, only that they were recovered in the Dar al-Mulk or Royal Residence, and the private residential area of the Alcazar (i. e., caliph's residence). A second group (25) was recovered in archaeological excavations during the 1980s and1990s. Of these, the largest group (15) came from the House of Ŷa'far al-Șiqlabī, the hayib or Prime Minister of the Caliphate State, which was constructed from 961 AD onwards. These sherds were recovered from the sanitation pipe system which was used as a dumping site for domestic waste and broken ceramics. One more sherd was found during the excavation in 1987 in the East Room adjacent of the Throne Room, six from the Pillar Courtyard, two from the Lower Footpath and one from the Portico. With the exception of two sherds from a closed form, possibly a small storage vessel, all these yellow glazed sherds come from the rims, bodies and foot-rings of serving bowls and dishes.

In addition, one opaque yellow glazed sherd from a serving dish was found in the recent archaeological excavations al-Munyat al-Rummaniyya, which was an estate west of Madīnat al-Zahrā' and built around 965 AD by Durrī al-Sagir, the Treasurer of the Umayyad Caliphate. After his death in $976 \mathrm{AD}$, the estate continued in use until its sacking and destruction in 1010 $\mathrm{AD}$ (Arnold et al. 2014). More recently, whilst writing this paper, three yellow glazed sherds, which appear to be opaque but have not yet been analysed, were identified from recent archaeological excavations in Cordoba and dated in the Caliphate period (929-1013 AD). One was found in the Caliphal Alcazar of Cordoba ("royal context"), and two in the areas to the west of Cordoba, known as al-Ŷānib al-Garbī-Ronda Oeste and plaza del poeta Ibn Zaydun, where an urban plan with new neighbourhoods was developed to meet the needs of the new Caliphal Administration at Madīnat al-Zahrā'. 
Opaque yellow glazed Islamic ceramics were first produced in Egypt (Coptic Glazed Ware) and Syria (Yellow Glazed Family Wares) in $7^{\text {th }} / 8^{\text {th }}$ centuries $\mathrm{AD}$, with lead stannate $\left(\mathrm{PbSnO}_{3}\right)$ as the opacifier. From there, the lead stannate yellow glaze technology spread eastwards into Iraq and Iran by $9^{\text {th }}$ century $A D$, and continued in use in Iran and Central Asia into the $10^{\text {th }}$ century AD and beyond (Tite et al. 2015; Matin 2016). Lead stannate yellow glazed sherds, dated to between the second half of the $8^{\text {th }}$ and early $11^{\text {th }}$ centuries $\mathrm{AD}$, have also been identified in excavations at Nishapur (Rante and Collinet 2013).

Yellow glazed ceramics of the Fayyumi I type, which are opacified with lead antimonate and date between mid- $9^{\text {th }}$ and end of $11^{\text {th }}$ centuries AD, are found in Egypt (Tite et al. 2015), and Waksman et al. (2017) have reported two lead antimonate yellow glazed sherds among a group of ceramics from Fustat dating between $9^{\text {th }}$ and $10^{\text {th }}$ centuries AD. In addition, Pradell (private communication) has identified lead antimonate in a yellow glazed ceramic, held in the Museu de Ceramica de Barcelona (MCB18710), which is most probably from Tunisia and is probably dated to late $9^{\text {th }}-10^{\text {th }}$ centuries $A D$. Also, in Tunisia, transparent yellow glazed ceramics, coloured by iron, were produced in Raqqada and Sabra al-Mansuriya in $10^{\text {th }}$ century AD (Ben Amara et al. 2001and 2005).

Either transparent or opaque yellow glazed ceramics dating to $9^{\text {th }}$ and $10^{\text {th }}$ centuries $\mathrm{AD}$ are relatively rare in al-Andalus. In fact, the large collection of opaque yellow glazed sherds found in Madīnat al-Zahrā' is exceptional both in terms of their relative abundance, but more importantly because of their well-defined context, being closely dated to about 960-980 AD during the Caliphate of al-Hakam II. At the beginning of this study neither the technological tradition nor their composition were known. In fact, the $20^{\text {th }}$ century historians disagreed with regard to its possible nature, transparent chrome glaze (Velázquez 1912, 77) or an antimony glaze (Gómez-Moreno 1951, 323; Torres 1965, 776) being suggested. Neither did they agree about the origin, either local (Gómez-Moreno 1951, 323; Valdés 1988) or imported (Heidenreich 2014, 22-23).

Therefore, a selection of eleven sherds from this group, in addition to one sherd from alRummaniyya, were analysed in polished section in a scanning electron microscope (SEM) with energy-dispersive spectrometry (EDS). These analyses were supplemented by X-ray diffraction (XRD) measurements on one of the glazes. The primary aims of these analyses were first, to determine the nature of the yellow particles (i.e., whether tin-based or antimony-based); second, to establish whether these ceramics were locally produced or imported from further east; and third, more generally, to find contemporary parallels and connections with other opaque yellow glazed ceramic production across the Islamic world.

\section{Experimental procedures}

\subsection{Glazed ceramic samples}

Eleven sherds were selected from those found at Madīnat al-Zahrā', ten being from those found in the early $20^{\text {th }}$ century excavations, and one (MZ6) from the East Rooms, adjacent to the Throne Room, which were excavated in 1987. In addition, one sherd found at al-Munyat alRummaniyya was included. The selection was made in order to include examples of the 
observed range of surface colours (i.e., yellow, green, brownish, and white), and vessel shapes (Figure 2). The yellow glaze was applied over the entire sherd and all the samples have both surfaces glazed, not only bowls and dishes, but also storage vessels. There are different colour combinations for the two surfaces (i.e., yellow-yellow, green-yellow, or white-yellow). Many of the ceramics were damaged with part of the glaze surface altered or lost. The interiors of some bowls and dishes appear decorated with single lines or dots, and simple vegetal patterns. The decorations are green and, sometimes, pearly white, although, due to the bad preservation state, it is difficult to know if this is an effect of the alteration. We have noted that the white glazes and pearly white decorations appear altered and in all the cases contained copper. The brownish colours of some surfaces are also related to alteration, which has resulted in the presence on the glaze surface of lead and calcium phosphates, and clay.

$<$ Figure 2>

\subsection{Analytical procedures}

Polished sections through the glazes and into the bodies of the sherds were prepared. The polished sections were examined both in reflected light with an optical microscope, and in a SEM with attached EDS. A crossbeam workstation (Zeiss Neon 40) equipped with SEM GEMINI (Shottky FE) column and EDS (INCAPentaFETx3 detector, 30 $\mathrm{mm}^{2}$, ATW2 window), operating at $20 \mathrm{KV}$ with 120s measuring times, were employed. The glaze and body microstructures were studied and recorded in backscatter mode (BSE) in which the different phases present could be distinguished on the basis of their atomic number contrast.

Chemical compositions of the bodies were determined by analysing a minimum of two areas, about $3 \mathrm{~mm} \times 2 \mathrm{~mm}$. Because of the porosity of the bodies, the analyses were normalised to $100 \mathrm{wt} \%$, and then averaged. For the glazes, the areas analysed were somewhat smaller, and as far as possible, were chosen to avoid areas of weathered glaze and areas near to the glaze-body interface, although this was not always possible in view of the heavily weathered glazes on some of the samples; the results were again averaged. A selection of the non-plastic inclusions within the bodies, and opacifier and other particles in the glazes were also analysed. The EDS system was calibrated using oxide and mineral standards with secondary high lead (K229) and alkali (SRM612) glass standards being used to validate the data. Typical absolute detection limits are $0.1 \%$ for $\mathrm{Na}, \mathrm{Mg}, \mathrm{Al}, \mathrm{P}, \mathrm{K}, \mathrm{Ca}, \mathrm{Ti}, \mathrm{Mn}$ and $\mathrm{Fe}, 0.2 \%$ for $\mathrm{Si}$ and $\mathrm{Cu}, 0.3 \%$ for $\mathrm{Sn}$ and $0.4 \%$ for $\mathrm{Pb}$.

XRD analysis of one of the yellow glazes (MZ5) was also performed to ascertain the nature of the crystalline particles present in the glaze. The surface of the glaze was directly measured using a. PANalytical X'Pert PRO MPD Alpha1 powder diffractometer with Bragg-Brentano $\theta / 2 \theta$, and $\mathrm{Cu} \mathrm{K} \alpha_{1}$ radiation. Measuring conditions were $4-100^{\circ} 2 \theta$, step size of $0.017^{\circ}$ and measuring time of 150 seconds.

\section{Results}

\subsection{Bodies}


The ceramic bodies appear very coarse, containing large grains (feldspars, quartz) visible to the eye, and consist of a variety of, up to three, unevenly mixed pastes of different texture, colour (from buff, through yellow and orange, to red) and sometimes composition (Figure 3). Under the optical microscope and SEM, biotite micas and ferruginous particles (Figures 3CD) are visible as well as small lead glass (Figures 4C and 4E) and barite (Figure 4F) fragments, probably derived from workshop debris. In addition, micro-foraminiferans or forams derived from marine plankton are present, some of which show complete structures, such as the Globigerine inside which dolomite crystallization has occurred (Figures 4A-B).

The heterogeneous textures, with badly mixed clays and the large grain sizes, associated with the bodies of the yellow glazed ceramics differ from those of the locally produced, polychrome, tin-opacified glazed ceramics which are fine and homogeneous. However, it should be noted that the locally produced ceramic bodies also contain biotite micas and microfossils, but crushed down to a very small size.

$<$ Figure 3>

$<$ Figure 4>

In spite of the observed heterogeneity of the bodies, the chemical compositions obtained for different areas of the polished sections were quite consistent, with only comparatively small standard deviations (Table 1). With the exception of that of MZ6 with a lime content of 7.2 wt $\% \mathrm{CaO}$, all the bodies contain high concentrations of lime $(12-28 \mathrm{wt} \% \mathrm{CaO})$, a significant proportion of which is present as microfossil fragments. Plots of $\mathrm{CaO}$ versus $\mathrm{MgO}$ contents show positive correlation, whereas increases in $\mathrm{CaO}$ and $\mathrm{MgO}$ contents are associated with decreases in $\mathrm{Al}_{2} \mathrm{O}_{3}, \mathrm{~K}_{2} \mathrm{O}$ and $\mathrm{FeO}$ contents. Again, it should be noted that the locally produced ceramic bodies are also produced from a clay containing high concentrations of lime (12 - 20 $\mathrm{wt} \% \mathrm{CaO})$

$<$ Table 1>

\subsection{Glazes}

The opaque yellow glazes appear heavily weathered with a significant loss of lead oxide, sometimes to a considerable depth below the glaze surface (Figures 5A-C). The glazes are opacified with lead stannate particles, but also contain some tin oxide particles (i.e., cassiterite) (Figures 6A-B), as well as some quartz grains. In spite of the weathering, these particles are still supported within the surviving amorphous matrix (Figures 5B-C). XRD analysis of the surface of the glaze of MZ5 (Figure 7) shows that the opacifier particles are of the type $\mathrm{Pb}_{2}(\mathrm{Sn}, \mathrm{Si})_{2} \mathrm{O}_{6}$. Quartz, and as a result of the alteration of the glaze, cerussite $\left(\mathrm{PbCO}_{3}\right)$ and hydrocerusssite $\left(\mathrm{Pb}_{3}\left(\mathrm{CO}_{3}\right)_{2} \cdot(\mathrm{OH})_{2}\right)$ were also detected.

$<$ Figure 5>

$<$ Figure 6>

<Figure 7> 
In the cross-section through sherd MZ5, a large fragment of lead glass $(150 \mu \mathrm{m} \times 160 \mu \mathrm{m})$, surrounded by growths of small diopside crystals, can be seen embedded into the surface of the body (Figures 5A-B). The presence of the lead glass suggests that the glaze was produced using a powdered mixture of lead glass and preformed lead stannate, the latter probably being obtained by melting together lead and tin metals (Matin 2016). Direct evidence of the use of a prefired lead glass to produce the lead glazes has also been found in the contemporary workshop from Sant Nicolas in Murcia (Molera et al 2009). The low reaction between the ceramic body and the glaze (Figures 5D and 6C) suggests a double firing, in which the powdered lead glass and lead stannate mixture was probably applied over a biscuit fired ceramic body. Since the lead stannate particles still retain their crystalline shapes, forming aggregates reflecting their original distribution within the glazing mixture (Figures 5C and 6A$\mathrm{B})$, the glaze was fired up to temperatures high enough for it to soften and adhere to the ceramic body, but not too high to homogenize the distribution of particles within the glaze.

The bulk chemical compositions of the opaque yellow and, where present, green glazes are given in Table 2 from which it can be seen that all the glazes, with the exception of those applied to sherd MZ6, are of the high lead type (62-68 wt\% PbO) containing only small amounts of alkali (typically $<0.9 \mathrm{wt} \% \mathrm{Na}_{2} \mathrm{O}+\mathrm{K}_{2} \mathrm{O}$ ) and alkaline earths (typically $<3.5 \mathrm{wt} \%$ $\mathrm{CaO}+\mathrm{MgO}$ ). Because of heavy weathering of these glazes, many of the analyses had to be made close to the glaze-body interface, and as a result, the alumina contents of the glazes are more variable, ranging from 0.5-2.1 wt $\% \mathrm{Al}_{2} \mathrm{O}_{3}$. The $\mathrm{MZ6}$ glazes have lower $\mathrm{PbO}$ contents compared to the other glazes (57-60 wt \%) and higher $\mathrm{Al}_{2} \mathrm{O}_{3}$ contents (2.6-3.8 wt \%). Therefore, they are similar in composition to that of the glass fragment embedded in the body of MZ5 (56 $\mathrm{wt} \% \mathrm{PbO}$ and $4.5 \mathrm{wt} \% \mathrm{Al}_{2} \mathrm{O}_{3}$ ), which perhaps suggests a larger reaction of the glaze with the ceramic body. In all the cases, the yellow glazes are colored by the lead stannate particles, and the green glazes by the addition of a few wt $\%$ of copper oxide.

\section{$<$ Table 2>}

The analysis of a selection of lead stannate particles indicated that they are of the form $\mathrm{Pb}\left(\mathrm{Sn}_{1}\right.$ $\left.x, \mathrm{Si}_{\mathrm{x}}\right) \mathrm{O}_{3}$, with $\mathrm{x}$ varying between 0.40 and 0.41 ), and $\mathrm{Sn} / \mathrm{Si}$ wt $\%$ ratios in the range $1.45-1.50$. By assuming that all the tin oxide was used in the formation of lead stannate, and that the $\mathrm{Sn} / \mathrm{Si}$ wt $\%$ ratio was equal to 1.5 , the wt $\%$ lead stannate particles in the glaze can be estimated, the average values for the yellow and green glazes being $24 \mathrm{wt} \%$ and $20 \mathrm{wt} \%$ respectively (Table 3). Also given in Table 3 are, first, the compositions of the background glazes determined by subtracting the wt $\%$ associated with the lead stannate particles plus copper colorant, and renormalizing to $100 \mathrm{wt} \%$ (i.e., * ${ }^{\mathrm{wt}} \%$ in Table 3 ), and second, the lead oxide contents $\left(\mathrm{PbO}_{\mathrm{BG}}\right)$ calculated by assuming that the background glazes were produced from a lead oxide-silica mixture; that is,

$$
\mathrm{PbO}_{\mathrm{BG}}=\mathrm{PbO}^{*} \times 100 /\left(\mathrm{PbO}^{*}+\mathrm{SiO}_{2}^{*}\right)
$$

\section{$<$ Table 3>}

The yellow and green background glazes can, therefore, be considered as being the result of 1 high lead glaze (i.e., $\mathrm{PbO}_{\mathrm{BG}}$ equal to $68 \mathrm{wt} \%$ ) which has dissolved some $2.6 \mathrm{wt} \% \mathrm{CaO}, 1.4$ wt $\% \mathrm{Al}_{2} \mathrm{O}_{3}$ and $1.5 \mathrm{wt} \% \mathrm{FeO}$ and below $0.5 \mathrm{wt} \%$ of $\mathrm{K}_{2} \mathrm{O}, \mathrm{MgO}$ and $\mathrm{Na}_{2} \mathrm{O}$. The enriched $\mathrm{CaO}$ 
and $\mathrm{Al}_{2} \mathrm{O}_{3}$ contents can be explained by the use of a lime-rich sandy layer to protect the inner surfaces of the crucibles from the molten glass, as was reported at a contemporary workshop in Sant Nicolas in Murcia (Molera et al. 2009). As a result, the glaze melt will be close to the eutectic composition (i.e., $70 \mathrm{wt} \% \mathrm{PbO}+30 \mathrm{wt} \% \mathrm{SiO}_{2}$ ), and will form near to the eutectic temperature of about $714^{\circ} \mathrm{C}$, or even slightly lower due to the presence of $\mathrm{Al}_{2} \mathrm{O}_{3}$ and $\mathrm{K}_{2} \mathrm{O}$. There is a competition between the melt and the lead stannate particles to acquire $\mathrm{PbO}$, and therefore, as the ratio of $\mathrm{PbO} / \mathrm{SiO}_{2}$ in the bulk glaze decreases, the lead oxide available for the lead stannate particles decreases and cassiterite precipitates. Thus, when the amount of $\mathrm{PbO}$ in the bulk glaze was kept high, the lead stannate particles were stable (Figures 5C and 6A-B), and more intense yellow glazes were produced. In contrast, when the amount of $\mathrm{PbO}$ was low, such as happens in MZ6, the lead stannate particles, having started to dissolve in the glaze, were very small and showed round edges, and paler yellow glazes were produced (Figures 6D). The need of a high lead glaze to obtain a stable yellow glaze was previously demonstrated by Tite et al. (2008).

\section{Discussion}

The above results clearly establish that the glazes used in the production of the opaque yellow glazed ceramics found at Madīnat al-Zahrā' were opacified and coloured using lead stannate. Further, the glaze technology employed matches that which was first introduced in Egypt and Syria in the $7^{\text {th }} / 8^{\text {th }}$ centuries $A D$, which spread eastwards into Iraq and Iran by the $9^{\text {th }}$ century $\mathrm{AD}$, and then continued in use into $10^{\text {th }}$ century AD and beyond in Iran and Central Asia. In contrast, in north Africa, in addition to the transparent yellow glazes produced in Tunisia (Ben Amara et al. 2001 and 2005), yellow glazes opacified with lead antimonate were being produced in Egypt in $9^{\text {th }}-11^{\text {th }}$ centuries AD (Tite et al. 2015; Waksman et al. 2017), and in Tunisia in $9^{\text {th }}-10$ th centuries AD.

In the context of the overall range of ceramics found at Madinat al-Zahrā', the amount of opaque yellow glazed ware is very small as compared to local productions in al-Andalus. The most extensive of these local productions was a transparent lead glazed ware which was mainly either honey or greenish coloured, and decorated with simple brown patterns using a manganese-based colorant. Although this ware has not been analysed, contemporary green, yellow and brown lead glazes from Murcia (Molera et al 2009) and from la Vega in Granada (Molera et al 2017) have been shown to be of the high lead type (50-54 wt\% PbO, and 45-52 $\mathrm{wt} \% \mathrm{PbO}$ respectively). In addition, a second distinctive local production was a polychrome "green and brown" decorated, tin-opacified glazed ware (Molera et al. 2001). The most distinctive forms of this production were serving dishes, but there were other forms, such as jars, pitchers and bottles (Escudero et al. 2015, 130-155). Since the largest concentration of "green and brown", tin-opacified glazed sherds was found at Madīnat al-Zahrā', this ware was most probably produced for the Umayyad court and for senior officials, and therefore, its main production centre was most likely to have been located in either Madīnat al-Zahrā' or Córdoba. Later some peripheral workshops emerged in other cities of al-Andalus, such as Murcia, Toledo and Sevilla, which produced "regional copies" from the end of the $10^{\text {th }}$ to $11^{\text {th }}$ centuries AD (Vallejo 2015). Again, the wares from Murcia have been analysed, and shown to contain 52$59 \mathrm{wt} \% \mathrm{PbO}$ and 2.0-2.7 wt\% $\mathrm{SnO}_{2}$ (Molera et al. 2009). 
The opaque yellow glazed ware was the most abundant of the luxury wares at Madinat alZahrā'. Other imported luxury wares were again found in the private area of the Alcazar, and included a large collection of lustre fragments found at the House of $\hat{Y} a$ 'far. Analysis of the lustre decoration, glazes and bodies of a selection of the lustre fragments suggests that these ceramics could have been imported from a production centre for monochrome lusterware in Abbasid Mesopotamia (Polvorinos et al. 2008).

In considering whether the opaque yellow glazed ceramics were locally produced in al-Andalus or imported from another part of the Islamic world, one should first note that there is no other evidence of the use or continuity of the yellow lead stannate opacification technology in Islamic Iberian Peninsula. Furthermore, the coarse and heterogeneous body fabrics of the Madinat alZahrā' sherds do not match those of any documented locally produced ceramics which, in contrast, are fine and homogeneous. However, it is also true that the opaque yellow glazed bodies match, in general terms, the locally produced ceramics, in that the bodies of both were produced using sedimentary lime-rich clays containing biotite micas and microfossils, which can be found in many locations. Therefore, although an al-Andulus origin remains a possibility, the opaque yellow glazed ceramics were not produced in the same local workshops as either the transparent or tin-opacified glazed ceramics. Also, stylistically, although the shapes of the wares match those of the polychrome "green and brown", tin-opacified glazed ware, the decorative patterns of the local wares are generally more complex including plant designs and epigraphic, zoomorphic and anthropomorphic patterns. The exception is sherd MZ6 whose type of decoration is close to that of the contemporary, locally produced, polychrome, tin-opacified glazed ceramics. Furthermore, MZ6, which was the single opaque yellow glazed sherd found in the East Room, differs from all the other Madinnat al-Zahrā' opaque yellow glazed ceramics in that, as discussed in the Results section, its body has a lower lime content, its glazes lower lead contents, and lead stannate particles in the glazes have started to dissolve. Therefore, even if the Madīnat al-Zahrā' opaque yellow glazed ceramics were produced locally, it is probable that at least two difference workshops were used.

Considering possible centres from which the Madīnat al-Zahrā' opaque yellow glazed wares could have been imported, ceramics with similar decoration but different shapes have been found in Raqqa in Syria and Susa in Iran, but both the Raqqa and Susa ceramics are earlier in date than those at Madīnat al-Zahrā'. In contrast, opaque yellow glazed ceramics with similar shapes and decoration to those from Madīnat al-Zahrā' have been documented in Nīshāpūr dating to the $9^{\text {th }}-10^{\text {th }}$ centuries AD. However, although their glaze compositions match, the body compositions of the few opaque yellow glazed ceramics from Nishapur analysed so far, do not match those of Madīnat al-Zahrā' (Rante et Collinet 2013; Moujan 2016). In particular, the Nishapur bodies have significantly higher soda contents $(1.2-1.8 \mathrm{wt} \%$ as compared to 0.4$\left.0.8 \mathrm{wt} \% \mathrm{Na}_{2} \mathrm{O}\right)$ and somewhat higher magnesia contents (2.5-6.1 wt\% as compared to 1.6-3.8 wt $\% \mathrm{MgO})$.

\section{Conclusion}

In summary, the glaze technology employed in the production of the opaque yellow glazed ware found at Madīnat al-Zahrā' was of the type which was first introduced into the Islamic world in Egypt and Syria in $7^{\text {th }} / 8^{\text {th }}$ centuries AD, and which continued in use in Iran and Central Asia through into the $10^{\text {th }}$ century $\mathrm{AD}$ and beyond. 
The fact that the opaque yellow glazed ware at Madinat al-Zahrā' is concentrated in the Alcazar, together with other imported luxury wares, indicates that its use was associated with the Caliph and those closest to him (i.e., his family and immediate court). Since both a significant proportion of the opaque yellow glazed ware was found in the House of Ya' far, and one opaque yellow glazed sherd was found on the estate of Durrī al-Sagir, the Treasurer of the Umayyad Caliphate, at al-Munyat al-Rummaniyya, the use of this ware can be dated to 960980 AD.

Neither the body fabric nor the glazing technology for the opaque yellow glazed ceramics found at Madīnat al-Zahrā' are entirely consistent with its local production, and therefore, it is possible that the ware was imported into medieval Spain. Since, in the production of opaque yellow glazed ceramics in Egypt and Tunisia in the $10^{\text {th }}$ century $\mathrm{AD}$, lead antimonate and not lead stannate was the opacifier, the Madinnat al-Zahrā' ceramics are most probably linked to those found in Iran or Central Asia. In fact, opaque yellow glazed ceramics with similar shapes and decoration to the Madīnat al-Zahrā' ware, and dating to $9^{\text {th }}-10^{\text {th }}$ centuries AD, were found at Nishapur. However, on the basis of the analytical data obtained so far, the Madīnat al-Zahrā' bodies have a different composition as compared to those from Nishapur.

One can perhaps argue that the low quality of the Madīnat al-Zahrā' bodies are inconsistent with the ware being a regular luxury trade good. Instead, one could argue that the group of opaque yellow glazed ware under investigation reached Madīnat al-Zahrā' with an embassy, as a present for the Caliph. For example, among others, a visit by a Byzantine embassy in 972 $\mathrm{AD}$ is documented. In this context, it should be noted that there is documentary evidence that a Byzantine artisan was brought to Cordoba during the al-Hakam II Caliphate (961-976 AD) in order to decorate the dome of the mihrab of Mosque Alhama with mosaics, and that the glass tesserae for making the mosaics also came from Byzantium (Stern 1976). These tesserae included opaque yellow glass tesserae which would have been produced in the Byzantine Empire using lead stannate as the opacifier (Freestone et al. 1990). However, although locally produced, opaque yellow glass would have been available to them, there is no evidence that Byzantine potters ever produced opaque yellow glazed ceramics. Therefore, if the Madinat alZahrā' ceramics were brought by a Byzantine embassy, there still remains the question of from where they were acquired.

Finally, an alternative to the import of opaque yellow glazed ceramics to Madinnat al-Zahrā', it is possible that the technology for their production reached al-Andalus as a result of the arrival of potters who then produced a small quantity of yellow glazed ware for the caliph court using coarse local clays for the bodies. The use of lead stannate, rather than lead antimonate, yellow links these potters to Iran or Central Asia, rather than to Egypt or Tunisia. This link would have been consistent with the historical fact that the Umayyad Caliphate, for example, through the building of Madinat al-Zahrā', was attempting to demonstrate its power at a time when the Fatimids were seen as a menace that was expanding across North Africa from Egypt through to Tunisia.

Thus, in summary, the lead stannate opacified, yellow glazed ceramics found in al-Andalus add one further, if as yet not fully understood, chapter to the story of a persistent glaze technology, which according to Watson (2014), began in the late $7^{\text {th }}-8^{\text {th }}$ century AD and then rapidly spread to many different locations within the Islamic world.

\section{Acknowledgements}


Elena Salinas is funded by the Marie Skłodowska-Curie Actions call H2020-MSCA-IF-2015 project IGATO. We are grateful to the funds received from Ministerio de Ciencia e Innovación (Spain) project MAT2016-N0748719-R and Generalitat de Catalunya project 2014 SGR 00581.

\section{References}

Arnold F, Canto A, Vallejo A (2014) Jardines de al-Rummaniyya (Córdoba). Memoria 2014

Ben Amara A, Schvoerer M, Daoulatli A, Rammah M (2001) "Jaune de Raqqada" et autres couleurs de céramiques glaçurées aghlabides de Tunisie (IX - X siècles). Revue d'Archéométrie 25:179-186

Ben Amara A, Schvoerer M, Thierrin-Michael, G, Rammah M (2005) Distinction de céramiques glaçurées aghlabides ou fatimides (IXe-XIe siècles, Ifriqiya) par la mise en évidence de différences de texture au niveau de l'interface glaçure - terre cuite. ArchéoSciences 29:35-42

Escudero J, García A, Muñoz JM, Zamorano A, Montejo AJ, Salinas E, Baena MD (2015) Madinat al-Zahra. Catálogo de la exposición permanente. Casa Árabe, Córdoba

Freestone IC, Bimson M, Buckton D (1990) Composition categories of Byzantine glass tesserae. Annales du $11^{\mathrm{e}}$ Congrès de l'Association Internationale pour l'Histoire du verre (Bale 1998), pp 271-279

Gómez-Moreno M (1951) El arte español hasta los Almohades. Ars Hispaniae III. Madrid.

Heidenreich A (2014) II. Cerámica. In: Arnold F, Canto A, Vallejo A (ed) Jardines de alRummaniyya (Córdoba). Memoria 2014

Matin M (2016) Revisiting the Origins of Islamic Glazed Pottery: A Technological Examination of 8th-10th Century AD Ceramics from Islamic Lands. University of Oxford DPhil thesis (unpublished).

Molera J, Pradell T, Salvadó N, Vendrell-Saz M (2009) Lead frits in Islamic and HispanoMoresque glazed productions. From Mine to Microscope. Advances in the Study of Ancient Technology. Oxford Books, Oxford, pp 1-10

Molera J, Vendrell-Saz M, Pérez-Arantegui, J (2001) Chemical and Textural Characterization of Tin Glazes in Islamic Ceramics from Eastern Spain, Journal of Archaeological Science 28:331-340

Molera J, Carvajal JC, Molina G, Pradell T (2017) Glazes, colourants and decorations in early Islamic glazed ceramics from the Vega of Granada ( $9^{\text {th }}$ to $12^{\text {th }}$ centuries CE). Journal of Archaeological Science Reports, in press, DOI:j.jasrep.2017.05.017

Polvorinos A, Castaing J, Roehrs S, Vallejo A, Escudero J (2008) Estudio arqueométrico de loza dorada de Madinat al-Zahra, Córdoba. Cuadernos de Madinat al-Zahra 6:165-179

Rante R, Collinet A (2013) Nishapur revisited. Stratigraphy and ceramics of the Qohandez. Oxbow Books, Oxford. Exeter

Tite M, Watson O, Pradell T, Matin M, Molina G, Domoney K, Bouquillon A (2015) Revisiting the beginnings of tin-opacified Islamic glazes. Journal of Archaeological Sciences 57:80-91 
Tite MS, Pradell T, Shortland A (2008) Discovery, production and use of tin-based opacifiers in glasses, enamels and glazes from the Late Iron Age onwards: a reassessment. Archaeometry 50:67-84

Torres L (1965) Arte Hispanomusulmán. Hasta la caída del Califato de Córdoba. Historia de España, V. Madrid, pp 339-378

Stern H (1976) Les mosaiques de la Grande Mosquée de Cordoue. Berlín

Valdés F (1988) La cerámica con vedrío amarillo de Madīnat al-Zahra'. Cuadernos de la Alhambra 24:15-23

Vallejo A (2010) La ciudad califal de Madinat al-Zahra. Arqueología de su arquitectura. Jaén Vallejo A (2013) Madinat al-Zahra: Historical Reality and Modern-day Heritage. Awraq 7:89109

Vallejo A (2015) Prólogo. In: González R, Aguilar L, Barrionuevo, FJ (ed) Los colores del poder. La cerámica en "verde y manganeso" de Jerez de la Frontera (Cádiz). Peripecias Libros, Cádiz, pp 7-13

Velázquez R (1912) Medina Azzahara y Alamiriya. Madrid

Waksman SY, Capelli C, Cabella R (2017) Annexe: Études en laboratoire de céramiques islamiques du Caire: l'apport des fouilles recentes. In: Gayraud R-P, Vallauri L (ed) Fustat II. Fouilles d'Isțabl 'Antar. Céramiques d'ensembles des $\mathrm{IX}^{\mathrm{e}}$ et $\mathrm{X}^{\mathrm{e}}$ siècles. Institut français d'archéologie orientale. Fouilles de l'Ifao 75/Institut d'Archéologie Orientale, Le Caire, pp $383-414$

Watson O (2014) Revisiting Samarra: the rise of the Islamic plazed pottery. Beiträge Zur Islamischen Kunst Und Archäologie 4:125-144 


\section{$\underline{\text { Figure and Table Captions }}$}
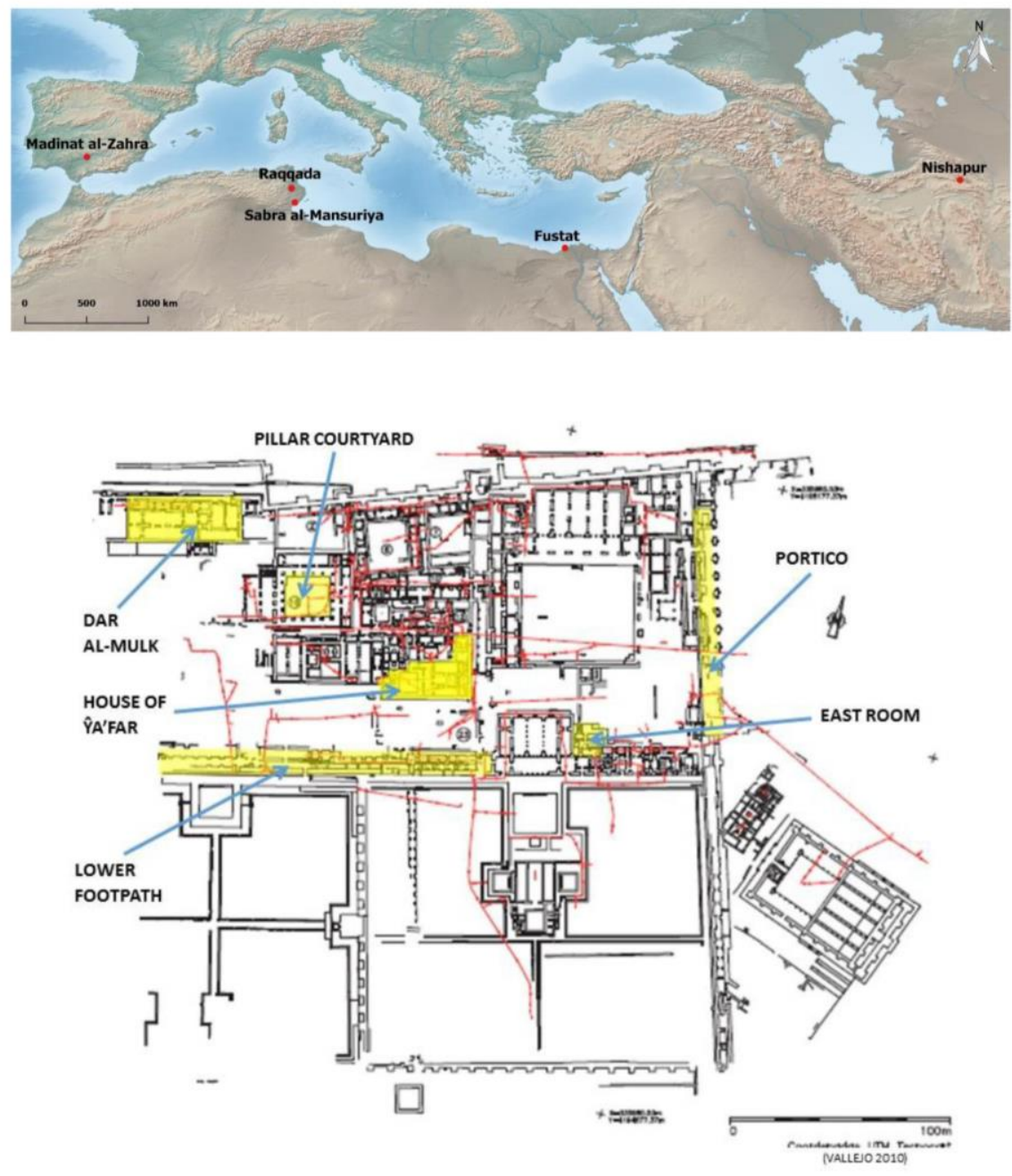

Figure 1. (A) Map showing locations of sites where opaque yellow glazed ceramics dating to second half of $10^{\text {th }}$ century AD have been found, and which are discussed in the present paper. (B) Plan of Madīnat al-Zahrā' archaeological site, showing areas in which opaque yellow glazed ceramics were found (from Vallejo 2010). 

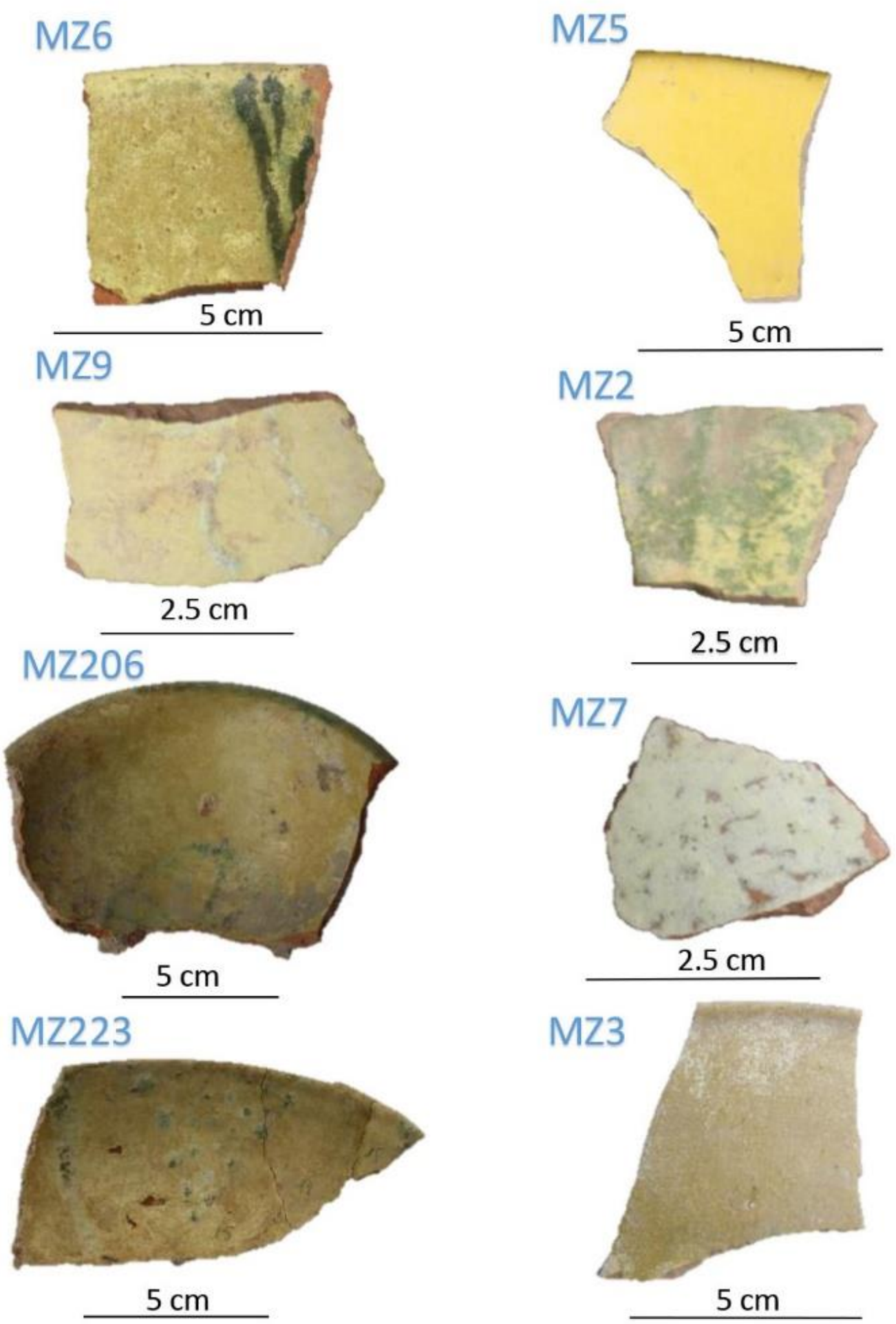

Figure 2. Representative opaque glazed ceramics from Madīnat al-Zahrā' showing the decorative geometrical patterns (dots, lines) (at left) and the observed glaze colours, from top to bottom, yellow, green, white and brown (at right). 

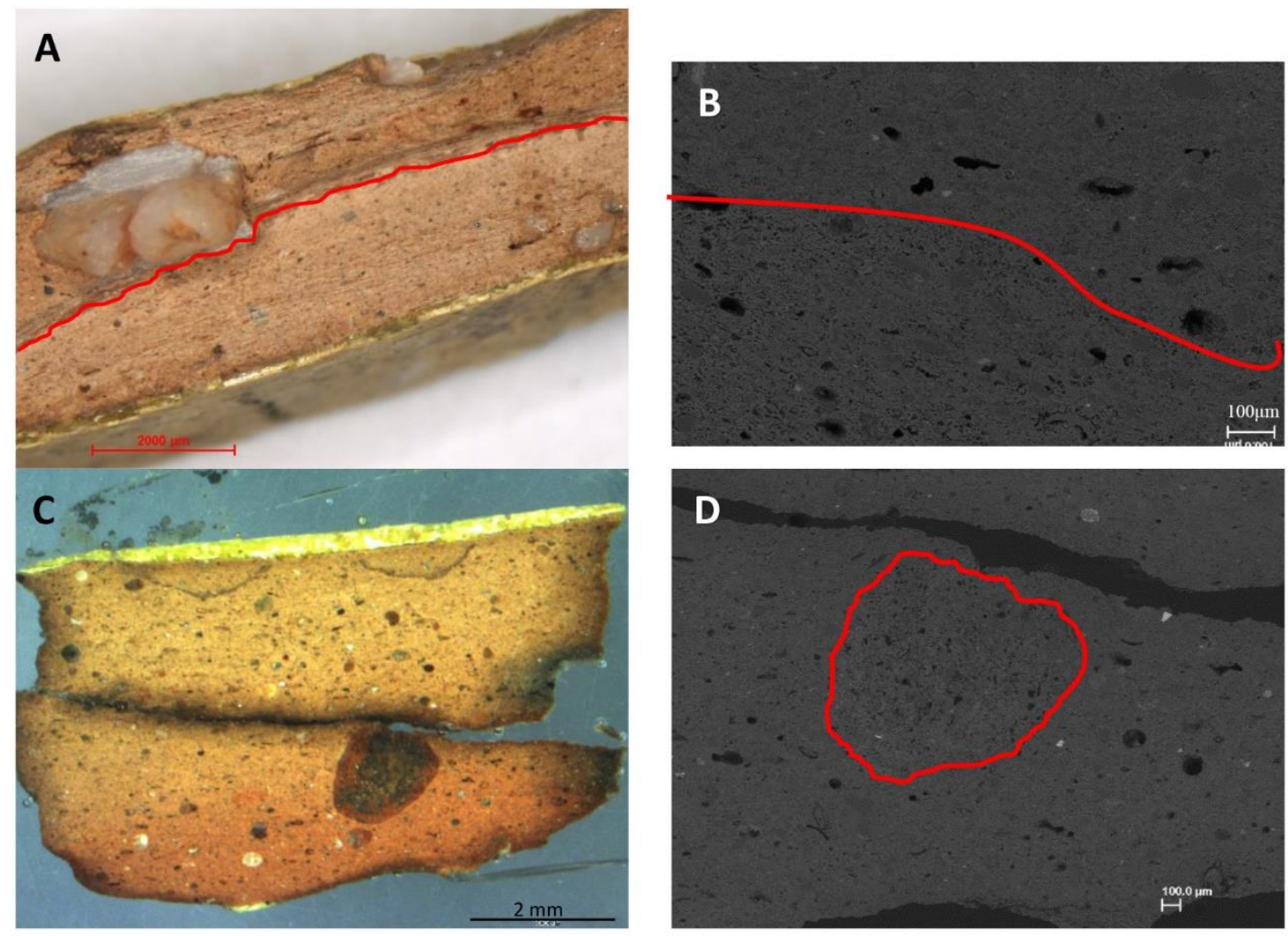

Figure 3. Typical ceramic fabrics showing badly mixed clays and coarse textures with large inclusions for sherds MZ5 ((A) Optical and (B) SEM-BSE images) and MZ9 ((C) Optical and (D) SEM-BSE images). The red line in (B) marks division between two textures clay types, and in (D) defines large ferruginous inclusion.
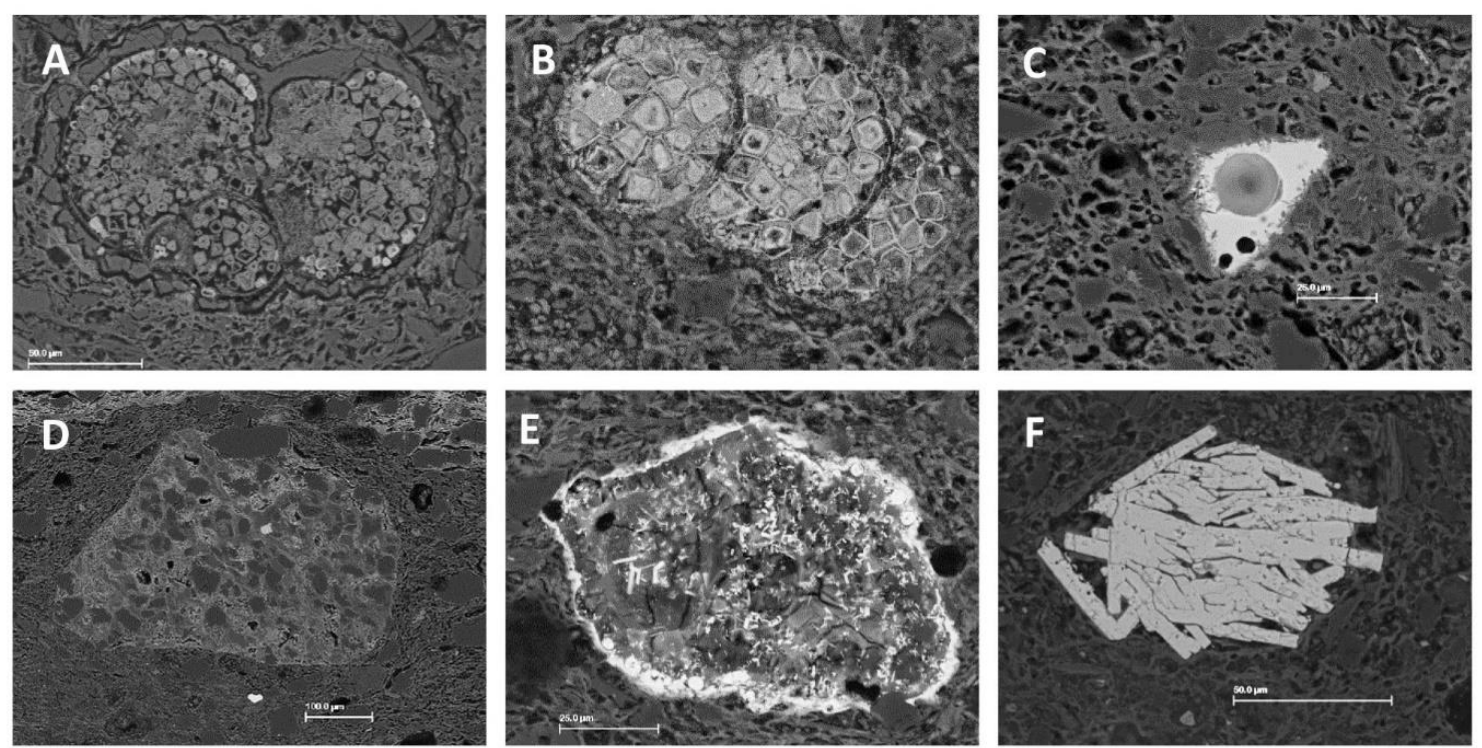

Figure 4. SEM-BSE images of characteristic inclusions found in the ceramic bodies: (A) and (B) globigerine foram fossils, (C) glass particle, (D) grog particle, (E) reacted glass particle, and $(\mathrm{F})$ barite $\left(\mathrm{BaSO}_{4}\right)$ fragment. 

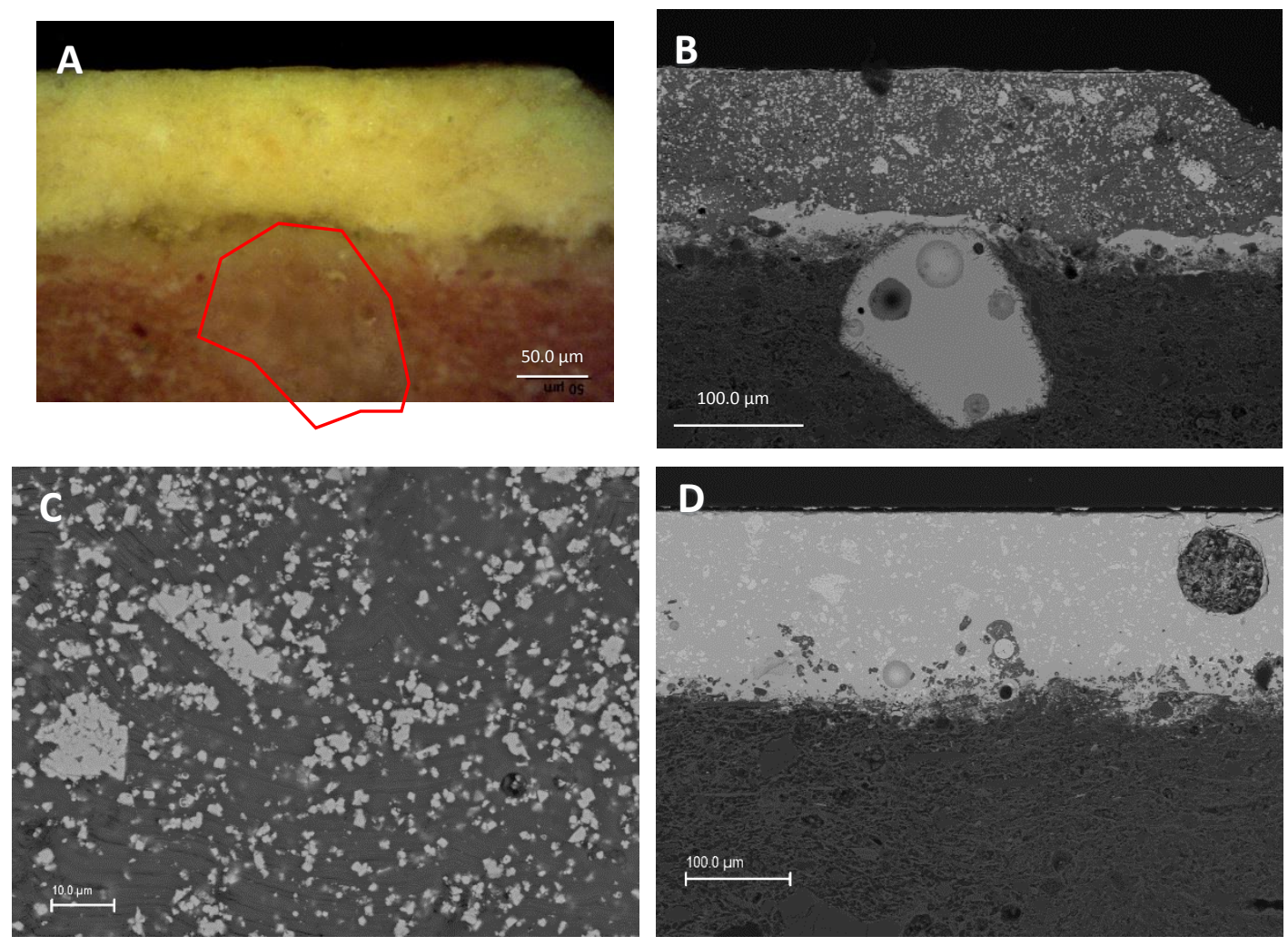

Figure 5. (A) Optical and (B) SEM-BSE images of the badly preserved glaze from MZ5 showing a large glass fragment embedded in surface of body; (C) SEM-BSE image of lead stannate particles visible in MZ5 glaze; and (D) SEM-BSE image of a well-preserved MZ1 glaze.
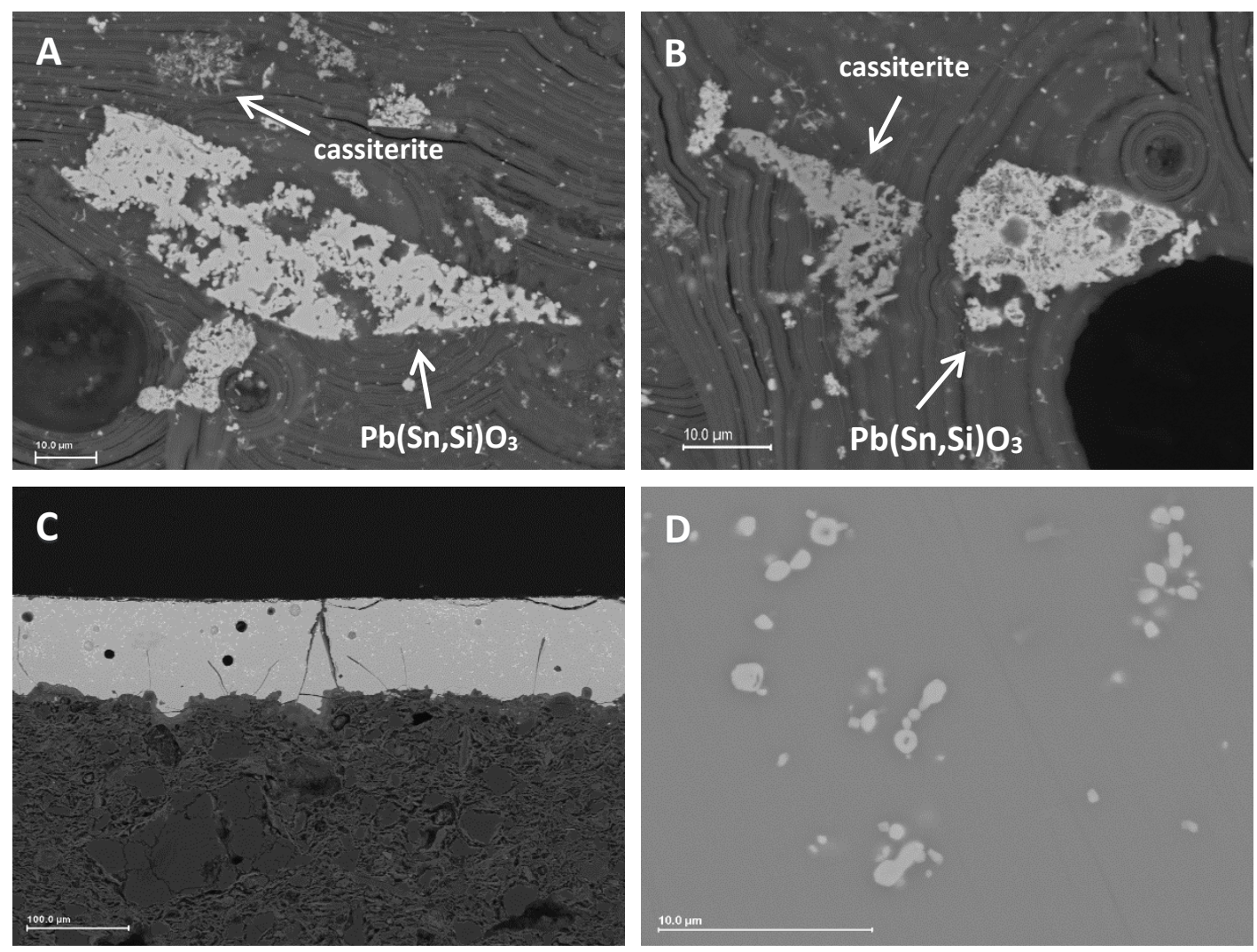
Figure 6. (A) and (B) SEM-BSE images of lead stannate and cassiterite particles visible in MZ7 glaze; (C) and (D) partially dissolved lead stannate particles visible in MZ6 glaze.
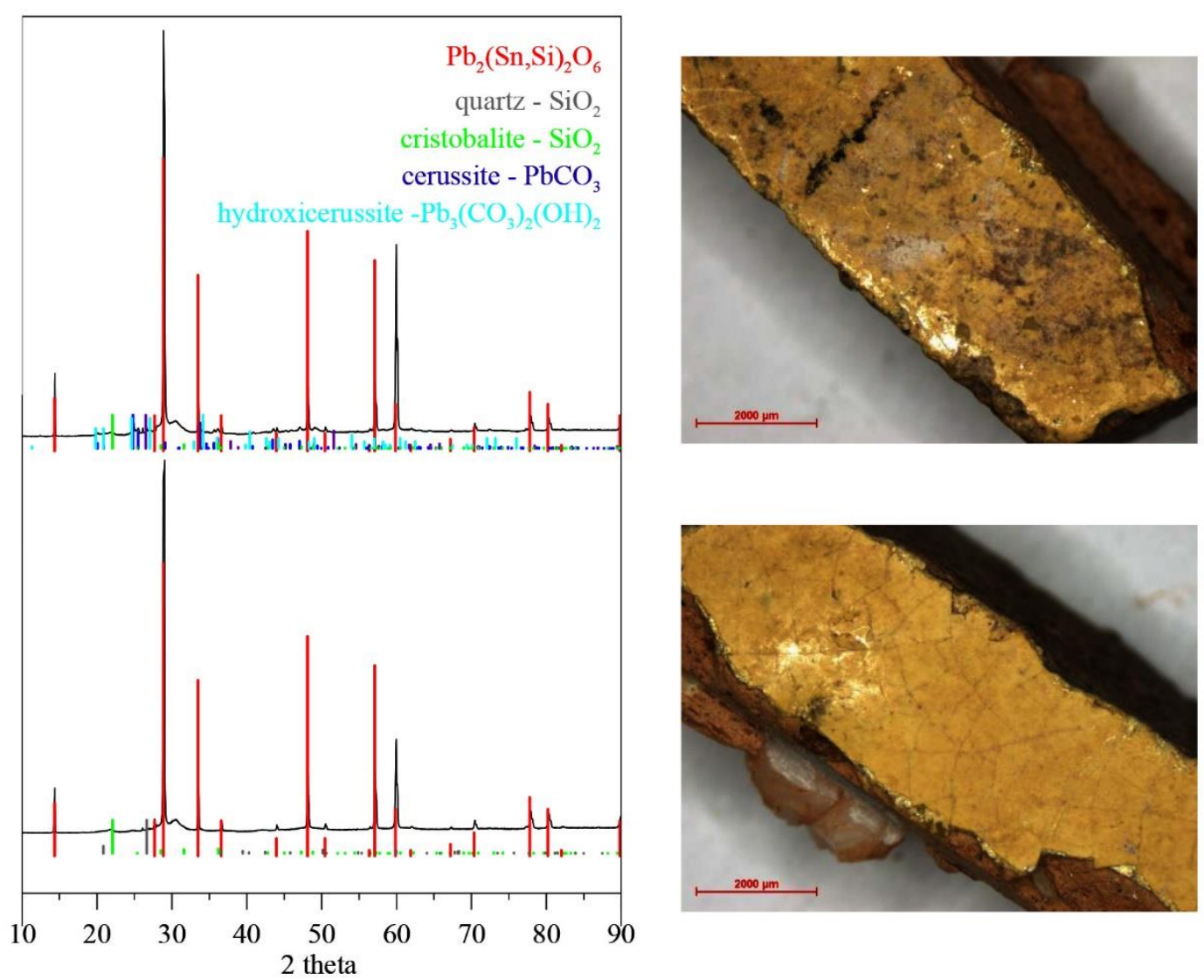

Figure 7. XRD spectra for the inner (upper) and outer (lower) yellow glazes of sherd MZ5. 
Table 1. Chemical compositions of the Madīnat al-Zahrā' ceramic bodies determined by SEMEDS (wt \% normalised to $100 \mathrm{wt} \%$ ). The data are the average over at least two analyses taken in different areas of the ceramic bodies.

\begin{tabular}{ccccccccccc}
\hline Sample & $\mathrm{Na}_{2} \mathrm{O}$ & $\mathrm{MgO}$ & $\mathrm{Al}_{2} \mathrm{O}_{3}$ & $\mathrm{SiO}_{2}$ & $\mathrm{~K}_{2} \mathrm{O}$ & $\mathrm{CaO}$ & $\mathrm{TiO}_{2}$ & $\mathrm{MnO}$ & $\mathrm{FeO}$ & $\mathrm{PbO}$ \\
\hline MZ1 & 0.5 & 2.5 & 12.9 & 45.6 & 2.5 & 27.6 & 0.6 & & 5.7 & 1.4 \\
MZ2 & 0.4 & 2.7 & 14.0 & 47.2 & 2.8 & 24.1 & 0.6 & & 6.1 & 1.1 \\
MZ3 & 0.5 & 2.5 & 15.2 & 54.8 & 2.7 & 17.0 & 0.6 & 0.2 & 5.2 & 1.1 \\
MZ4 & 0.5 & 3.8 & 13.9 & 47.4 & 2.7 & 23.3 & 0.5 & 0.2 & 5.3 & 1.6 \\
MZ5 & 0.4 & 2.1 & 14.2 & 52.4 & 2.8 & 19.2 & 0.6 & & 6.6 & 1.1 \\
MZ6 & 0.5 & 1.6 & 14.9 & 64.0 & 3.2 & 7.2 & 0.8 & 0.2 & 7.0 & 0.4 \\
MZ7 & 0.4 & 1.7 & 13.8 & 59.8 & 3.0 & 12.3 & 0.6 & 0.1 & 6.6 & 1.3 \\
MZ8 & 0.7 & 1.8 & 15.7 & 55.5 & 3.2 & 14.0 & 0.8 & 0.2 & 6.8 & 1.2 \\
MZ9 & 0.5 & 1.7 & 15.3 & 54.4 & 3.5 & 14.3 & 0.8 & 0.2 & 7.4 & 1.9 \\
MZ10 & 0.4 & 2.5 & 13.1 & 43.1 & 2.6 & 27.4 & 0.8 & & 6.5 & 3.3 \\
MZ11 & 0.8 & 2.1 & 14.9 & 56.6 & 2.6 & 12.5 & 0.9 & 0.1 & 6.7 & 2.0 \\
RUM & 0.6 & 2.4 & 14.4 & 52.2 & 2.8 & 18.6 & 0.7 & & 6.2 & 1.7 \\
\hline
\end{tabular}


. Table 2. Chemical compositions of Madīnat al-Zahrā' bulk glazes determined by SEM-EDS (wt\% normalised to $100 \mathrm{wt} \%$ ). The data are the average over at least two analyses taken in different areas of the glazes. Typical standard deviations are: 0.3 for $\mathrm{Na}_{2} \mathrm{O}, \mathrm{MgO}, \mathrm{K}_{2} \mathrm{O}, \mathrm{FeO}$ and $\mathrm{PbO}, 0.4$ for $\mathrm{CuO}$ and $\mathrm{Sn}_{2} \mathrm{O}, 0.9$ for $\mathrm{Al}_{2} \mathrm{O}_{3}$ and $\mathrm{SiO}_{2}$, and 1.5 for $\mathrm{CaO}$.

\begin{tabular}{|c|c|c|c|c|c|c|c|c|c|c|c|c|}
\hline Sample & Glaze $^{1}$ & Side $^{2}$ & $\mathrm{Na}_{2} \mathrm{O}$ & $\mathrm{MgO}$ & $\mathrm{Al}_{2} \mathrm{O}_{3}$ & $\mathrm{SiO}_{2}$ & $\mathrm{~K}_{2} \mathrm{O}$ & $\mathrm{CaO}$ & $\mathrm{FeO}$ & $\mathrm{CuO}$ & $\mathrm{SnO}_{2}$ & $\mathrm{PbO}$ \\
\hline \multirow{2}{*}{ MZ1 } & $y$ & $\mathrm{i}$ & 0.3 & 0.4 & 1.1 & 24.0 & 0.4 & 2.6 & 1.4 & & 6.0 & 63.7 \\
\hline & $y$ & 0 & 0.1 & 0.2 & 1.0 & 21.8 & 0.3 & 2.0 & 2.0 & & 8.6 & 64.1 \\
\hline \multirow{2}{*}{ MZ2 } & $y$ & $\bar{i}$ & 0.2 & 0.3 & 1.2 & 24.0 & 0.5 & 2.4 & 0.7 & 1.3 & 5.8 & 63.7 \\
\hline & g & 0 & 0.4 & 0.3 & 1.2 & 23.5 & 0.3 & 2.2 & 0.9 & 1.7 & 4.3 & 65.0 \\
\hline \multirow{2}{*}{ MZ3 } & $y$ & $\mathrm{i}$ & 0.3 & 0.3 & 1.6 & 24.9 & 0.4 & 2.5 & 1.2 & & 4.8 & 64.0 \\
\hline & $\mathbf{g}$ & 0 & 0.3 & 0.3 & 1.1 & 23.0 & 0.4 & 2.1 & 1.1 & 1.7 & 6.6 & 65.0 \\
\hline \multirow[b]{2}{*}{ MZ5 } & & 0 & 0.2 & 0.2 & 1.2 & 22.8 & 0.4 & 2.0 & 2.0 & & 4.5 & 66.3 \\
\hline & $\begin{array}{c}\text { Glass } \\
\text { fragment }\end{array}$ & & 0.8 & 0.4 & 4.5 & 31.4 & 1.2 & 3.1 & 2.3 & & 0.4 & 55.6 \\
\hline \multirow{3}{*}{ MZ6 } & $\mathrm{g}^{*}$ & $i$ & 0.3 & 0.5 & 3.8 & 29.6 & 0.9 & 2.4 & 2.1 & 2.3 & 1.9 & 55.9 \\
\hline & y & 0 & 0.4 & 0.6 & 2.6 & 27.8 & 1.3 & 2.4 & 2.0 & & 3.0 & 59.9 \\
\hline & $y$ & i & 0.2 & 0.5 & 3.5 & 28.9 & 0.7 & 2.3 & 2.3 & & 3.2 & 58.2 \\
\hline \multirow{2}{*}{ MZ7 } & $y$ & $i$ & 0.1 & 0.1 & 2.1 & 29.5 & 0.3 & 1.2 & 0.7 & & 3.4 & 62.4 \\
\hline & g & 0 & 0.2 & 0.2 & 1.1 & 28.4 & 0.4 & 1.9 & 0.5 & 1.3 & 1.8 & 64.1 \\
\hline MZ9 & $y$ & 0 & 0.2 & 0.2 & 0.7 & 24.5 & 0.5 & 0.9 & 0.4 & & 4.6 & 68.0 \\
\hline \multirow{2}{*}{ MZ10 } & $y$ & $\mathrm{i}$ & 0.3 & 0.2 & 1.0 & 25.3 & 0.4 & 2.1 & 0.8 & & 5.0 & 64.8 \\
\hline & $y$ & 0 & 0.3 & 0.2 & 0.5 & 24.4 & 0.4 & 1.3 & 0.9 & & 5.8 & 66.2 \\
\hline \multirow{2}{*}{ MZ11 } & $y$ & 0 & 0.3 & 0.2 & 0.5 & 24.4 & 0.4 & 1.3 & 0.9 & & 5.8 & 66.2 \\
\hline & $y$ & $\mathrm{i}$ & 0.3 & 0.2 & 1.3 & 24.3 & 0.4 & 2.4 & 0.9 & & 6.9 & 63.3 \\
\hline \multirow{2}{*}{ RUM1 } & $y$ & $\bar{i}$ & 0.3 & 0.6 & 1.3 & 24.5 & 0.4 & 2.4 & 1.2 & & 5.9 & 63.3 \\
\hline & $y$ & 0 & 0.1 & 0.6 & 1.0 & 22.2 & 0.6 & 2.5 & 1.1 & & 6.0 & 66.0 \\
\hline
\end{tabular}

${ }^{1} \mathrm{y}$ - yellow glaze, g- green or white glaze, $\mathrm{g} *$ - green decoration

2 i - inner glaze, o - outer glaze 
Table 3. Chemical compositions of the Madīnat al-Zahrā' bulk glazes after subtraction of contributions from the colorants (i.e., lead stannate particles and copper oxide) (wt\% normalised to $100 \%$ ). The lead oxide contents ( $\mathrm{wt} \% \mathrm{PbO}_{\mathrm{BG}}$ ), calculated assuming that the background glazes were produced from a lead oxide-silica mixture, and the calculated wt $\%$ lead stannate particles are also given. The average composition of the yellow and green glazes are calculated without including the glass fragment from MZ5 and the glazes from MZ6.

\begin{tabular}{|c|c|c|c|c|c|c|c|c|c|c|c|c|}
\hline Sample & Glaze $^{1}$ & Side $^{2}$ & $\mathrm{Na}_{2} \mathrm{O}^{*}$ & MgO* & $\mathrm{Al}_{2} \mathrm{O}_{3} *$ & $\mathrm{SiO}_{2}{ }^{*}$ & $\mathrm{~K}_{2} \mathrm{O}^{*}$ & $\mathrm{CaO} *$ & $\mathrm{FeO}^{*}$ & PbO* & $\begin{array}{l}\text { \%wt } \\
\mathrm{PbO}_{\mathrm{BG}}\end{array}$ & $\begin{array}{l}\text { \%wt lead } \\
\text { stannate } \\
\text { particles }\end{array}$ \\
\hline \multirow{2}{*}{ MZ1 } & $y$ & $\mathrm{i}$ & 0.3 & 0.6 & 1.5 & 30.0 & 0.6 & 3.5 & 1.8 & 61.7 & 67 & 25 \\
\hline & $y$ & 0 & 0.2 & 0.3 & 1.5 & 30.5 & 0.5 & 3.2 & 3.1 & 60.7 & 67 & 36 \\
\hline \multirow{2}{*}{ MZ2 } & $y$ & i & 0.3 & 0.4 & 1.5 & 30.2 & 0.6 & 3.2 & 1.0 & 62.8 & 68 & 26 \\
\hline & g & 0 & 0.5 & 0.4 & 1.5 & 27.9 & 0.4 & 2.8 & 1.1 & 65.3 & 70 & 20 \\
\hline \multirow{2}{*}{ MZ3 } & $y$ & $\mathrm{i}$ & 0.3 & 0.4 & 2.0 & 29.5 & 0.6 & 3.1 & 1.5 & 62.6 & 68 & 20 \\
\hline & g & 0 & 0.5 & 0.4 & 1.5 & 29.4 & 0.5 & 2.9 & 1.6 & 63.2 & 68 & 28 \\
\hline \multirow[b]{2}{*}{ MZ5 } & & 0 & 0.3 & 0.3 & 1.5 & 26.8 & 0.5 & 2.5 & 2.4 & 65.6 & 71 & 19 \\
\hline & $\begin{array}{c}\text { Glass } \\
\text { fragment }\end{array}$ & & 0.9 & 0.4 & 4.6 & 31.7 & 1.2 & 3.2 & 2.3 & 55.2 & 64 & 1 \\
\hline \multirow{3}{*}{ MZ6 } & $\mathrm{g}^{*}$ & $\mathrm{i}$ & 0.4 & 0.5 & 4.2 & 32.5 & 1.0 & 2.7 & 2.3 & 56.0 & 63 & 10 \\
\hline & $y$ & 0 & 0.4 & 0.7 & 3.0 & 30.9 & 1.5 & 2.8 & 2.3 & 58.4 & 65 & 13 \\
\hline & y & $\mathrm{i}$ & 0.2 & 0.5 & 4.1 & 32.5 & 0.8 & 2.7 & 2.7 & 56.5 & 63 & 14 \\
\hline \multirow{2}{*}{ MZ7 } & $y$ & $\mathrm{i}$ & 0.1 & 0.1 & 2.5 & 33.4 & 0.3 & 1.5 & 0.8 & 61.3 & 65 & 14 \\
\hline & g & 0 & 0.2 & 0.2 & 1.3 & 30.6 & 0.4 & 2.1 & 0.5 & 64.5 & 68 & 9 \\
\hline MZ9 & y & 0 & 0.3 & 0.2 & 0.8 & 28.9 & 0.6 & 1.1 & 0.5 & 67.6 & 70 & 19 \\
\hline \multirow{2}{*}{ MZ10 } & y & $\mathrm{i}$ & 0.4 & 0.3 & 1.2 & 30.4 & 0.4 & 2.6 & 1.0 & 63.6 & 68 & 21 \\
\hline & y & 0 & 0.4 & 0.3 & 0.6 & 30.2 & 0.5 & 1.7 & 1.1 & 65.2 & 68 & 24 \\
\hline \multirow{2}{*}{ MZ11 } & y & 0 & 0.4 & 0.3 & 0.6 & 30.2 & 0.5 & 1.7 & 1.1 & 65.2 & 68 & 24 \\
\hline & $y$ & $\mathrm{i}$ & 0.4 & 0.3 & 1.9 & 31.6 & 0.6 & 3.3 & 1.2 & 60.7 & 66 & 29 \\
\hline \multirow{2}{*}{ RUM1 } & $y$ & $i$ & 0.4 & 0.8 & 1.7 & 30.5 & 0.5 & 3.2 & 1.6 & 61.4 & 67 & 25 \\
\hline & $y$ & 0 & 0.2 & 0.7 & 1.3 & 27.5 & 0.8 & 3.3 & 1.4 & 64.4 & 70 & 25 \\
\hline \multirow{2}{*}{ Average } & $y$ & & 0.3 & 0.4 & 1.4 & 30.0 & 0.5 & 2.6 & 1.5 & 63.3 & 68 & 24 \\
\hline & g & & 0.4 & 0.4 & 1.5 & 29.5 & 0.5 & 2.7 & 1.0 & 63.9 & 68 & 20 \\
\hline
\end{tabular}

${ }^{1} \mathrm{y}$ - yellow glaze, $\mathrm{g}$ - green or white glaze, $\mathrm{g}^{*}$ - green decoration

2 i - inner glaze, o - outer glaze 